\title{
ANALISIS FAKTOR-FAKTOR YANG MEMPENGARUHI KEPUTUSAN KONSUMEN DALAM PEMBELIAN BARANG ELEKTRONIK SECARA KREDIT PADA PT COLUMBUS MEGAH SENTRA SARANA CABANG BERAU
}

\author{
Warti Ratnasari \\ Warti.amin@gmail.com \\ Universitas Muhammadiyah Berau
}

\begin{abstract}
This study aims to analyze the factors that influence consumer decisions to purchase electronic goods on credit at PT Columbus Megah Sentra Sarana, Berau Branch. The data collection method used a questionnaire distributed to consumers of PT Columbus Megah Sentra Sarana, Berau Branch, as many as 92 people who were selected using probability sampling method with simple random sampling technique. The analytical tools used are: validity test, reliability test, multiple linear regression analysis, coefficient of determination, $t$ test and $F$ test.

The results of this study indicate that the factors that have a significant influence are cultural factors, social factors and personal factors. Meanwhile, psychological factors have no significant effect on consumer decisions in purchasing electronic goods on credit at PT Columbus Megah Sentra Sarana, Berau Branch. So that the hypothesis of point 1 can be partially accepted and partially rejected.

The results of the $F$ test show that cultural factors, social factors, personal factors and psychological factors simultaneously have a significant influence on consumer decisions in purchasing electronic goods on credit at PT Columbus Megah Sentra Sarana, Berau Branch, so the hypothesis point 2 can be accepted.
\end{abstract}

Key words: Purchasing Decisions, Cultural Factors, Social Factors, Personal Factors and Psychological Factors

\section{PENDAHULUAN}

Daya beli masyarakat terhadap barang elektronik berkembang pesat contohnya adalah pembelian produk elektronik seperti televisi, DVD/VCD player, komputer, laptop, handphone, AC, hingga perabot rumah tangga seperti setrika, magic com, kipas angin, kulkas, blender, dan lainlain membuat semakin berkembang dan bertambahnya pelaku bisnis di bidang elektronik ini.

Upaya untuk mendatangkan dan mempertahankan konsumen, yaitu dengan cara menumbuhkan minat beli konsumen dan akhirnya melakukan keputusan membeli tidak mudah. Proses peng-ambilan keputusan pembelian pada setiap orang pada dasarnya adalah sama, yang membedakan adalah dalam proses pengambilan keputusan tersebut yang diwarnai beberapa hal diantaranya oleh ciri kepribadian, usia, pendapatan dan gaya hidup.
Perilaku konsumen sangat dipeng-aruhi oleh keadaan dan situasi masyarakat dimana ia dilahirkan dan berkembang. Ini berarti konsumen berasal dari lapisan masyarakat atau lingkungan yang berbeda akan mempunyai penilaian, kebutuhan, pendapat, sikap dan selera yang berbeda-beda, sehingga pengambilan keputusan dalam tahap pembelian akan dipengaruhi oleh banyak faktor.

Menurut Kotler dan Armstrong (2012:200) pembelian konsumen sangat dipengaruhi oleh karakteristik budaya, sosial, pribadi dan psikologis. Sebagian besar dari faktor-faktor itu tidak dapat dikendalikan oleh pemasar, namun mereka harus mempertimbangkannya. Selanjut-nya menurut kotler dan Armstrong (2012:215) pilihan barang yang dibeli seseorang lebih lanjut dipengaruhi oleh faktor psikologis yang penting yaitu motivasi, persepsi, pembelajaran serta kepercayaan dan sikap.

PT Columbus Megah Sentra Sarana Cabang Berau yang bergerak dalam penjualan alat-alat 
elektronik dan funiture harus bisa men-datangkan konsumen dan mempertahankan konsumennya yaitu dengan jalan mempengaruhi keputusan konsumen dalam melakukan pembelian. PT Columbus Megah Sentra Sarana Cabang Berau harus bisa melihat apa yang diinginkan dan apa yang dibutuhkan konsumen terhadap produk yang dipasarkannya. Sebelum memahami peri-laku konsumen lebih dahulu PT Columbus Megah Sentra Sarana Cabang Berau harus dapat memahami sikap konsumennya, karena sikap merupakan salah satu faktor psikologis yang dapat mempengaruhi perilaku konsumen dalam proses pembelian suatu produk. Apabila PT Columbus Megah Sentra Sarana Cabang Berau mampu untuk memahami sikap konsumennya maka perusahaan ini akan dapat mengambil keputusan pemasaran-nya dengan baik.

Sesuai dengan uraian di atas, penulis tertarik untuk membahas dan mengetahui faktor-faktor apa saja yang dapat mempengaruhi keputusan pembelian konsumen dan penulis memberikan judul skripsi ini yaitu: "Analisis Faktor-Faktor yang Mempengaruhi Keputusan Kon-sumen dalam Pembelian Barang Elektro-nik Secara Kredit pada PT Columbus Megah Sentra Sarana Cabang Berau."

\section{TINJAUAN TEORETIS}

\section{Manajemen Pemasaran}

Menurut Kotler dan Keller (2016:27) pengertian pemasaran adalah "Marketing management as the art and science of choosing target, keeping and growing customers through creating, delivering and communicating superior customer value". Pengertian pemasaran menurut Swastha (2009) adalah sistem keseluruhan dari kegiatan usaha yang ditujukan untuk merencanakan, menentukan harga, mempromosikan dan mendistribusikan barang, jasa, ide kepada pasar sasaran agar dapat mencapai tujuan organisasi.

Definisi pemasaran menurut Assauri (2015:5) adalah kegiatan manusia yang diarahkan untuk memenuhi dan memuaskan kebutuhan dan keinginan melalui proses pertukaran. Definisi tersebut bertumpu pada konsep pokok sebagai berikut: kebutuhan, keinginan dan permintaan, produk, nilai (value) dan kepuasan, pertukaran atau transaksi, pasar serta pemasaran dan pemasar.

\section{Perilaku Konsumen}

Perilaku konsumen (consumer behaviour) menurut Sunyoto (2015:251) dapat didefinisikan sebagai kegiatan-kegiatan individu yang secara langsung terlibat dalam mendapatkan dan mempergunakan barang/jasa termasuk didalamnya proses pengambilan keputusan pada persiapan dan penentuan kegiatan tersebut. Ada dua elemen penting dari perilaku konsumen itu: proses pengambilan keputusan, dan kegiatan fisik, yang semua ini melibatkan individu dalam menilai, mendapatkan dan menggunakan barang/jasa secara ekonomis. Dalam perkembangan konsep pemasaran yang mutakhir, konsumen ditempatkan sebagai sentral perhatian.

Menurut Engel et al. (2006) dalam Sangadji dan Sopiah (2013:7), perilaku konsumen adalah tindakan yang langsung terlibat dalam pemerolehan, pengonsumsi dan penghabisan produk/jasa, termasuk proses yang mendahului dan menyusul tindakan ini. Menurut Mowen dan Minor (2002) Sangadji dan Sopiah (2013:7), perilaku konsumen adalah studi di unit-unit dan proses pembuatan keputusan yang terlibat dalam penerimaan, penggunaan dan pembelian, dan penentuan barang, jasa, dan ide. Menurut Kotler (2005) dalam Sangadji dan Sopiah (2013:8), menjelaskan perilaku konsumen sebagai suatu studi tentang unit pembelian bisa perorangan, kelompok atau organisasi. Masingmasing unit tersebut akan membentuk pasar sehingga muncul pasar individu atau pasar konsumen, unit pembelian kelompok dan pasar bisnis yang dibentuk organisasi.

\section{Keputusan Pembelian}

Kotler dalam Sunyoto (2015:42) menerangkan bahwa keputusan pembelian adalah tindakan dari konsumen untuk mau membeli atau tidak terhadap suatu produk. Dari berbagai faktor yang mempengaruhi konsumen dalam melakukan pembelian suatu produk atau jasa, biasanya konsumen selalu mempertimbangkan kualitas, harga dan produk sudah yang sudah dikenali oleh masyarakat

\section{METODE PENELITIAN \\ Definisi Operasional}

Definisi operasional dimaksudkan untuk memberikan penjelasan mengenai variabel yang digunakan dalam penelitian ini, yaitu:

1) Keputusan Pembelian (Y) sebagai variabel terikat didefinisikan sebagai suatu tindakan dari konsumen untuk mau membeli atau tidak terhadap barang elektronik secara kredit pada PT Columbus Megah Sentra Sarana Cabang Berau. Indikator penilaian yang digunakan adalah:

a) Kemantapan pada sebuah produk: memanfaatkan pilihan terhadap barang 
elektronik atau memper-timbangkan berbagai pilihan.

b) Kebiasaan dalam membeli produk: Memutuskan untuk membeli barang elektronik.

c) Memberikan rekomendasi kepada orang lain: Memberikan rekomen-dasi kepada orang lain tentang barang elektronik PT Columbus Megah Sentra Sarana Cabang Berau.

d) Melakukan pembelian ulang: membeli kembali/membeli pada waktu yang lain.

2) Faktor Kebudayaan (X1) sebagai variabel bebas dengan indikator:

a) Budaya: Kebiasaan konsumen membeli suatu barang elektronik.

b) Sub-budaya: Memilih barang elektronik karena dipengaruhi oleh kelompok pergaulan.

c) Kelas Sosial: Minat membeli barang elektronik karena pengaruh lingkungan.

3) Faktor Sosial (X2) sebagai variabel bebas dengan indikator:

a) Kelompok Referensi (acuan): Rekan sekerja sebagai referensi dalam membeli barang elektronik.

b) Keluarga: Keluarga sebagai referensi dalam membeli barang elektronik.

c) Peran dan Status dalam masyarakat: Rekan sekomunitas sebagai referensi dalam membeli barang elektronik.

4) Faktor Pribadi (X3) sebagai variabel bebas dengan indikator:
a) Usia dan Tahap siklus hidup: Usia responden yang membeli barang elektronik.
b) Pekerjaan: Tingkatan/jenis pekerjaan.
c) Keadaan Ekonomi: Penghasilan yang didapatkan untuk membeli barang elektronik.
d) Gaya Hidup: Membeli barang elektronik sebagai gaya hidup.
e) Kepribadian: Kepribadian/senang melakukan sesuatu.

5) Faktor Psikologis (X4) sebagai variabel bebas dengan indikator:

a) Motivasi: Dorongan diri dalam membeli barang elektronik.

b) Persepsi: Persepsi dalam membeli barang elektronik.

c) Kepercayaan dan Sikap: Peng-alaman diri saat membeli barang elektronik.

\section{Unit Analisis, Populasi dan Sampel}

Unit analisis yang digunakan dalam penelitian ini adalah PT Columbus Megah Sentra Sarana Cabang Berau yang beralamat di Jalan Durian III Tanjung Redeb Kabupaten Berau.

Populasi dalam penelitian ini adalah konsumen PT Columbus Megah Sentra Sarana Cabang Berau yang berjumlah 1.130 orang. Sampel yang digunakan dalam penelitian ini adalah sejumlah 92 orang, dihitung menggunakan rumus slovin.

Metode pengambilan sampel yang digunakan dalam penelitian ini adalah Probability Sampling, dengan teknik Simple Random Sampling

\section{ALAT ANALISIS}

Alat analisis yang digunakan dalam penelitian ini dilakukan dengan bantuan program Statistical Package for Social Science (SPSS), terdiri atas: uji validitas, uji reliabilitas, regresi linier berganda, koefisien determinasi, uji $\mathrm{t}$ dan uji $\mathrm{F}$

\section{DATA HASIL PENELITIAN}

Sampel sebanyak 92 orang responden yang merupakan konsumen PT Columbus Megah Sentra Sarana Cabang Berau, dipilih menggunakan metode probability sampling dengan teknik simple random sampling. Responden dapat dikelompok-kan berdasarkan: jenis kelamin, umur, pendidikan, pekerjaan, penghasilan dan barang elektronik yang dikredit. Berikut gambaran umum mengenai responden.

\section{Gambaran Umum Responden}

Tabel 1. Gambaran Responden Menurut Jenis Kelamin

\begin{tabular}{|c|c|c|}
\hline Jenis Kelamin & Jumlah (orang) & Persentase (\%) \\
\hline Laki-laki & 30 & 32,61 \\
\hline Perempuan & 62 & 67,39 \\
\hline Total & $\mathbf{9 2}$ & $\mathbf{1 0 0}$ \\
\hline
\end{tabular}

Tabel 2. Gambaran Responden Menurut Umur

\begin{tabular}{|c|c|c|}
\hline Kelompok Umur & Jumlah (orang) & Persentase (\%) \\
\hline Dibawah 20 tahun & - & - \\
\hline$>20$ s/d 25 tahun & 5 & 5,44 \\
\hline$>25$ s/d 35 tahun & 61 & 66,30 \\
\hline$>35$ tahun & 26 & 28,26 \\
\hline Total & $\mathbf{9 2}$ & $\mathbf{1 0 0}$ \\
\hline
\end{tabular}

Tabel 3. Gambaran Responden Menurut Pendidikan

\begin{tabular}{|c|c|c|}
\hline Pendidikan Terakhir & Jumlah (orang) & Persentase (\%) \\
\hline Sekolah Dasar & 1 & 1,09 \\
\hline SMP & 5 & 5,44 \\
\hline SMA/SMK & 58 & 63,04 \\
\hline Diploma/Sarjana & 28 & 30,43 \\
\hline Total & 92 & 100 \\
\hline
\end{tabular}


Tabel 4. Gambaran Responden Menurut Pekerjaan

\begin{tabular}{|c|c|c|}
\hline Jenis Pekerjaan & Jumlah (orang) & Persentase (\%) \\
\hline Karyawan Bank & 1 & 1,09 \\
\hline Karyawan Swasta & 39 & 42,38 \\
\hline Pegawai Honorer & 4 & 4,35 \\
\hline Pekerja Tambang & 8 & 8,70 \\
\hline PNS & 24 & 26,09 \\
\hline Usaha Dagang & 16 & 17,39 \\
\hline Total & 92 & 100 \\
\hline
\end{tabular}

Tabel 5. Gambaran Responden Menurut Penghasilan

\begin{tabular}{|c|c|c|}
\hline Jumlah Penghasilan & Jumlah (orang) & Persentase (\%) \\
\hline$\leq 1$ juta & - & - \\
\hline$>1$ s/d 3 juta & 19 & 20,65 \\
\hline$>3$ s/d 5 juta & 62 & 67,39 \\
\hline$>5$ juta & 11 & 11,96 \\
\hline Total & $\mathbf{9 2}$ & $\mathbf{1 0 0}$ \\
\hline Sumber: Diolah dari hasil kuesioner, 2018.
\end{tabular}

Tabl 6. Gambaran Responden Menurut Barang Yang Dikredit

\begin{tabular}{|c|c|c|}
\hline Jumlah Penghasilan & Jumlah (orang) & Persentase (\%) \\
\hline Air Conditioner & 6 & 6,52 \\
\hline Televisi & 24 & 26,09 \\
\hline Mesin Cuci & 16 & 17,39 \\
\hline Handphone & 15 & 16,30 \\
\hline Lemari Es & 12 & 13,04 \\
\hline Freezer & 6 & 6,52 \\
\hline Laptop & 2 & 2,17 \\
\hline Showcase & 2 & 2,17 \\
\hline Speaker Aktif & 9 & 9,78 \\
\hline Total & 92 & 100 \\
\hline
\end{tabular}

\section{a.Jawaban Responden}

Tabel 7. Hasil Jawaban Responden Terhadap Keputusan Pembelian

\begin{tabular}{|c|c|c|c|c|c|c|c|}
\hline \multirow{2}{*}{ No. } & \multirow{2}{*}{ Pertanyaan } & \multicolumn{5}{|c|}{ Hasil Jawaban } & \multirow{2}{*}{ Jumlah } \\
\hline & & SS & $\mathbf{S}$ & $\mathbf{R}$ & TS & STS & \\
\hline 1 & Kemantapan & 18 & 47 & 27 & - & - & 92 \\
\hline 2 & Kebiasaan & 5 & 56 & 28 & 3 & - & 92 \\
\hline 3 & Rekomendasi & 17 & 59 & 16 & - & - & 92 \\
\hline 4 & Pembelian Ulang & 24 & 38 & 28 & 2 & - & 92 \\
\hline & Jumlah & 64 & 200 & 99 & 5 & - & 368 \\
\hline
\end{tabular}

Tabel 8. Hasil Jawaban Responden Terhadap Faktor Kebudayaan

\begin{tabular}{|c|l|c|c|c|c|c|c|}
\hline \multirow{2}{*}{ No. } & \multirow{2}{*}{ Pertanyaan } & \multicolumn{5}{|c|}{ Hasil Jawaban } & \multirow{2}{*}{ Jumlah } \\
\cline { 3 - 8 } & & SS & S & R & TS & STS & \\
\hline $\mathbf{1}$ & Budaya & 16 & 60 & 16 & - & - & 92 \\
\hline 2 & Sub Budaya & 21 & 59 & 10 & 2 & - & 92 \\
\hline 3 & Kelas Sosial & 17 & 57 & 18 & - & - & 92 \\
\hline \multicolumn{2}{|c|}{ Jumlah } & $\mathbf{5 4}$ & $\mathbf{1 7 6}$ & $\mathbf{4 4}$ & $\mathbf{2}$ & - & $\mathbf{2 7 6}$ \\
\hline
\end{tabular}

Tabel 9. Hasil Jawaban Responden Terhadap Faktor Sosial

\begin{tabular}{|c|c|c|c|c|c|c|c|}
\hline \multirow[b]{2}{*}{ No. } & \multirow{2}{*}{ Pertanyaan } & \multicolumn{5}{|c|}{ Hasil Jawaban } & \multirow{2}{*}{ Jumlah } \\
\hline & & SS & $\mathbf{S}$ & $\mathbf{R}$ & TS & STS & \\
\hline 1 & Kelompok Referensi & 15 & 50 & 27 & - & - & 92 \\
\hline 2 & Keluarga & 23 & 39 & 28 & 2 & - & 92 \\
\hline 3 & Peran \& Status & 3 & 55 & 33 & 1 & - & 92 \\
\hline & Jumlah & 4 & 144 & 88 & 3 & - & 276 \\
\hline
\end{tabular}

Tabel 10. Hasil Jawaban Responden Terhadap Faktor Pribadi

\begin{tabular}{|c|c|c|c|c|c|c|c|}
\hline \multirow[b]{2}{*}{ No. } & \multirow{2}{*}{ Pertanyaan } & \multicolumn{5}{|c|}{ Hasil Jawaban } & \multirow{2}{*}{ Jumlah } \\
\hline & & SS & $\mathbf{S}$ & $\mathbf{R}$ & TS & STS & \\
\hline 1 & Usia & 18 & 52 & 21 & 1 & - & 92 \\
\hline 2 & Pekerjaan & 16 & 46 & 30 & - & - & 92 \\
\hline 3 & Keadaan Ekonomi & 11 & 55 & 24 & 2 & - & 92 \\
\hline 4 & Gaya Hidup & 24 & 38 & 30 & - & - & 92 \\
\hline 5 & Kepribadian & 17 & 54 & 21 & - & - & 92 \\
\hline & Jumlah & 86 & 245 & 126 & 3 & - & 460 \\
\hline
\end{tabular}

Tabel 11. Hasil Jawaban Responden Terhadap Faktor Psikologis

\begin{tabular}{|c|c|c|c|c|c|c|c|}
\hline \multirow{2}{*}{ No. } & \multirow{2}{*}{ Pertanyaan } & \multicolumn{5}{|c|}{ Hasil Jawaban } & \multirow[b]{2}{*}{ Jumlah } \\
\hline & & SS & $\mathrm{S}$ & $\mathbf{R}$ & TS & STS & \\
\hline 1 & Motivasi & 21 & 41 & 26 & 4 & - & 92 \\
\hline 2 & Persepsi & 14 & 59 & 18 & 1 & - & 92 \\
\hline 3 & Kepercayaan & 5 & 54 & 32 & 1 & - & 92 \\
\hline & Jumlah & 40 & 154 & 76 & 6 & - & 276 \\
\hline
\end{tabular}

\section{ANALISIS DAN PEMBAHASAN}

Analisis

\section{Uji Validitas}

Tabel 12. Validitas Pertanyaan

\begin{tabular}{|l|c|c|c|}
\hline Item Pertanyaan & r-hitung & r-tabel & Keterangan \\
\hline Kemantapan & 0,591 & 0,205 & Valid \\
\hline Kebiasaan & 0,708 & 0,205 & Valid \\
\hline Rekomendasi & 0,516 & 0,205 & Valid \\
\hline Pembelian Ulang & 0,724 & 0,205 & Valid \\
\hline Budaya & 0,908 & 0,205 & Valid \\
\hline Sub Budaya & 0,644 & 0,205 & Valid \\
\hline Kelas Sosial & 0,892 & 0,205 & Valid \\
\hline Referensi & 0,680 & 0,205 & Valid \\
\hline Keluarga & 0,811 & 0,205 & Valid \\
\hline Peran \& Status & 0,720 & 0,205 & Valid \\
\hline Usia & 0,758 & 0,205 & Valid \\
\hline Pekerjaan & 0,711 & 0,205 & Valid \\
\hline Ekonomi & 0,679 & 0,205 & Valid \\
\hline Gaya Hidup & 0,625 & 0,205 & Valid \\
\hline Kepribadian & 0,613 & 0,205 & Valid \\
\hline Motivasi & 0,845 & 0,205 & Valid \\
\hline Persepsi & 0,765 & 0,205 & Valid \\
\hline Kepercayaan & 0,654 & 0,205 & Valid \\
\hline
\end{tabular}

Sumber: Data diolah, 2018.

Tabel di atas menunjukkan bahwa seluruh item pertanyaan mempunyai nilai r-hitung lebih besar dari nilai r-tabel sehingga dapat dinyatakan semua item pertanyaan valid.

\section{Uji Reliabilitas}

Tabel 13. Reliabilitas Pertanyaan

\begin{tabular}{|l|c|c|c|}
\hline \multicolumn{1}{|c|}{ Item Pertanyaan } & $\begin{array}{c}\text { Cronbach } \\
\text { Alpha }\end{array}$ & Kriteria & Keterangan \\
\hline Keputusan Pembelian & 0,510 & 0,7 & Tidak Reliabel \\
\hline Faktor Kebudayaan & 0,738 & 0,7 & Reliabel \\
\hline Faktor Sosial & 0,574 & 0,7 & Tidak Reliabel \\
\hline Faktor Pribadi & 0,702 & 0,7 & Reliabel \\
\hline Faktor Psikologis & 0,627 & 0,7 & Tidak Reliabel \\
\hline
\end{tabular}

Tabel di atas menunjukkan bahwa nilai cronbach alpha dari faktor kebudayaan dan faktor pribadi lebih besar dari 0,7 sehingga dapat disimpulkan item-item pertanyaan kedua faktor tersebut sudah reliabel. 
Sedangkan keputusan pembelian, faktor sosial dan faktor psikologis nilai cronbach alpha lebih kecil dari 0,7 sehingga dapat disimpulkan bahwa tidak reliabel.

\section{Analisis Regresi Linier Berganda}

Analisis ini digunakan untuk mengetahui pengaruh variabel bebas (faktor kebudayaan, sosial, pribadi dan psikologis) terhadap variabel terikat (keputusan pembelian).

Tabel 14. Hasil Output SPSS: Analisis Regresi Linier Berganda

\begin{tabular}{|c|c|c|c|c|}
\hline & \multirow{2}{*}{ Model } & \multicolumn{2}{|c|}{ Unstandardized Coefficients } & \multirow{2}{*}{$\begin{array}{c}\begin{array}{c}\text { Standardized } \\
\text { Coefficients }\end{array} \\
\text { Beta }\end{array}$} \\
\hline & & B & Std. Error & \\
\hline \multirow[t]{5}{*}{1} & (Constant) & ,351 &, 320 & \\
\hline & Kebudayaan & ,122 & ,053 & 145 \\
\hline & Sosial &, 552 &, 062 &, 642 \\
\hline & Pribadi & 198 & ,063 & ,215 \\
\hline & Psikologis & ,048 &, 056 & ,058 \\
\hline
\end{tabular}

Sumber: Data diolah 2018

Berdasarkan tabel di atas, pengujian regresi linier berganda menunjukkan nilai koefisien regresi masing-masing variabel, yang selanjutnya dibuat persamaan regresi linier berganda, sebagai berikut:

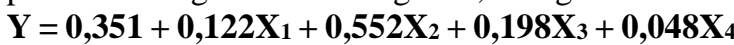
Dari persamaan regresi di atas dapat diketahui bahwa:

1. Nilai konstanta adalah 1,557 dan bertanda positif.

2. Koefisien regresi faktor kebudayaan sebesar 0,122 dan bertanda positif atau searah.

3. Koefisien regresi faktor sosial sebesar 0,552 dan bertanda positif atau searah.

4. Koefisien regresi faktor pribadi sebesar 0,198 dan bertanda positif atau searah.

5. Koefisien regresi faktor psikologis sebesar 0,048 dan bertanda positif atau searah.

Hasil pengujian regresi linier berganda di atas menunjukkan bahwa faktor sosial $\left(\mathrm{X}_{2}\right)$ merupakan faktor yang paling dominan pengaruhnya terhadap keputusan pembelian karena koefisien regresinya paling besar dibandingkan dengan variabel yang lain yaitu sebesar 0,552 .

Koefisien Determinasi

Tabel 15. Hasil Output SPSS: Koefisien Determinasi (Model Summary)

\begin{tabular}{|l|r|r|c|c|}
\hline Model & $R$ & R Square & $\begin{array}{c}\text { Adjusted R } \\
\text { Square }\end{array}$ & $\begin{array}{c}\text { Std. Error of the } \\
\text { Estimate }\end{array}$ \\
\hline 1 &, $828^{3}$ &, 685 &, 671 &, 248 \\
\hline
\end{tabular}
a. Predictors: (Constant), Psikologis, Kebudayaan, Pribadi, Sosial
Sumber: Data diolah, 2018.

Dari tabel di atas diketahui bahwa nilai koefisien determinasi ( $R$ Square) sebesar 0,685, yang berarti faktor kebudayaan, sosial, pribadi dan psikologis memberikan sumbangan pengaruh sebesar $68,5 \%$ terhadap keputusan konsumen dalam pembelian barang elektronik secara kredit pada PT Columbus Megah Sentra Sarana Cabang Berau. Sedangkan sisanya sebesar $31,5 \%$ dipengaruhi oleh variabel lain diluar penelitian ini.

\section{Uji t}

Tabel 16. Hasil Output SPSS: Uji t (Coefficients)

\begin{tabular}{|c|c|c|c|c|c|c|}
\hline & \multirow{2}{*}{ Model } & \multicolumn{2}{|c|}{$\begin{array}{l}\text { Unstandardized } \\
\text { Coefficients }\end{array}$} & \multirow{2}{*}{$\begin{array}{c}\begin{array}{c}\text { Standardized } \\
\text { Coefficients }\end{array} \\
\text { Beta }\end{array}$} & \multirow[t]{2}{*}{$t$} & \multirow{2}{*}{ Sig. } \\
\hline & & B & Std. Error & & & \\
\hline \multirow[t]{5}{*}{1} & (Constant) & .351 & 320 & & 1,097 & ,276 \\
\hline & Kebudayaan & .122 &, 053 & ,145 & 2,320 &, 023 \\
\hline & Sosial & ,552 &, 062 &, 642 & 8,889 & .000 \\
\hline & Pribadi & 198 & ,063 & .215 & 3,139 & .002 \\
\hline & Psikologis & .048 & ,056 &, 058 & 857 & ,394 \\
\hline
\end{tabular}

Sumber: Data diolah, 2018.

Berdasarkan tabel di atas dapat diketahui:

1. Faktor Kebudayaan

Nilai t-hitung $=2,320$ dan nilai t-tabel $=1,988$. Dapat ditentukan bahwa: t-hitung > t-tabel atau 2,320 > 1,988. Maka Ho diterima artinya faktor kebudayaan berpengaruh signifikan terhadap keputusan pembelian.

2. Faktor Sosial

Nilai t-hitung $=8,889$ dan nilai t-tabel $=1,988$. Dapat ditentukan bahwa: t-hitung > t-tabel atau $8,889>1,988$. Maka Ho diterima, artinya faktor sosial berpengaruh signifikan terhadap keputusan pembelian.

3. Faktor Pribadi

Nilai t-hitung $=3,139$ dan nilai t-tabel $=1,988$. Dapat ditentukan bahwa: t-hitung > t-tabel atau $3,139>1,988$. Maka Ho diterima, artinya faktor pribadi berpengaruh signifikan terhadap keputusan pembelian.

4. Faktor Psikologis

Nilai t-hitung $=0,857$ dan nilai $\mathrm{t}$-tabel $=1,988$. Dapat ditentukan bahwa: t-hitung $<\mathrm{t}$-tabel atau $0,857<1,988$.

Maka Ho ditolak, artinya faktor psikologis tidak berpengaruh signifikan terhadap keputusan pembelian.

\section{Uji F}

Tabel 17. Hasil Output SPSS: Uji F (ANOVA)

\begin{tabular}{|l|r|r|r|r|r|}
\hline Model & Sum of Squares & df & $\begin{array}{c}\text { Mean } \\
\text { Square }\end{array}$ & F & Sig. \\
\hline 1 Regression & 11,590 & 4 & 2,898 & 47,300 &, $000^{\mathrm{b}}$ \\
Residual & 5,330 & 87 &, 061 & & \\
$\quad$ Total & 16,920 & 91 & & & \\
\hline
\end{tabular}

a. Dependent Variable: Keputusan Pembelian

b. Predictors: (Constant), Psikologis, Kebudayaan, Pribadi, Sosial Sumber: Data diolah, 2018.

Berdasarkan tabel di atas dapat diketahui nilai Fhitung sebesar 47,30. Sedangkan nilai F-tabel 
sebesar 2,48 dengan $\alpha=0,05 ; \mathrm{df}_{1}=4$ dan $_{\mathrm{df}_{2}}=92$ $1-4=87$. Dengan demikian dapat ditentukan bahwa nilai F-hitung > F-tabel atau 47,30>2,48. Maka dapat disimpulkan bahwa faktor kebudayaan, sosial, pribadi dan psikologis secara bersama-sama mempunyai pengaruh signifikan terhadap keputusan pembelian.

\section{Pembahasan}

Hasil pengujian regresi linier berganda mendapat persamaan regresi linier berganda, sebagai berikut: $Y=0,351+0,122 X_{1}+0,552 X_{2}+0,198 X_{3}+0,048 X_{4}$ Interpretasi dari persamaan regresi di atas adalah sebagai berikut:

Nilai konstanta adalah 0,351 dan bertanda positif. Ini berarti bahwa dalam keadaan tetap atau tidak ada pengaruh dari faktor kebudayaan, sosial, pribadi dan psikologis, maka nilai keputusan pembelian sebesar 1,557 satuan.

Koefisien regresi faktor kebudayaan bertanda positif sebesar 0,122. Hal ini menunjukkan bahwa faktor kebudayaan berpengaruh positif dan searah terhadap keputusan pembelian. Apabila nilai faktor kebudayaan naik 1 satuan, maka nilai keputusan pembelian juga akan naik sebesar 0,122 satuan dengan asumsi nilai faktor lainnya tetap. Begitupun sebaliknya, apabila terdapat penurunan nilai faktor kebudayaan, maka nilai keputusan pembelian akan bergerak turun.

Koefisien regresi faktor sosial bertanda positif sebesar 0,552. Hal tersebut menunjukkan bahwa faktor sosial berpengaruh positif dan searah terhadap keputusan pembelian. Apabila nilai faktor sosial naik 1 satuan, maka nilai keputusan pembelian juga akan naik sebesar 0,552 satuan dengan asumsi nilai faktor lainnya tetap. Begitupun sebaliknya, apabila terdapat penurunan nilai faktor sosial, maka nilai keputusan pembelian juga akan bergerak turun.

Koefisien regresi faktor pribadi bertanda positif sebesar 0,198 . Hal tersebut menunjukkan bahwa faktor pribadi berpengaruh positif dan searah terhadap keputusan pembelian. Apabila nilai faktor pribadi naik 1 satuan, maka nilai keputusan pembelian juga akan naik sebesar 0,198 satuan dengan asumsi nilai faktor lainnya tetap. Begitupun sebaliknya, apabila nilai faktor pribadi turun, maka nilai keputusan pembelian juga akan bergerak turun. Koefisien regresi faktor psikologis bertanda positif sebesar 0,048. Hal tersebut menunjukkan bahwa faktor psikologis berpengaruh positif dan searah terhadap keputusan pembelian. Apabila nilai faktor psikologis naik 1 satuan, maka nilai keputusan pembelian juga akan naik sebesar 0,048 satuan dengan asumsi nilai faktor lainnya tetap. Begitupun sebaliknya, apabila nilai faktor psikologis turun, maka nilai keputusan pembelian juga akan bergerak turun.

Hasil persamaan regresi linier berganda tersebut di atas juga menunjuk-kan bahwa faktor sosial merupakan dimensi yang mempunyai pengaruh paling dominan terhadap keputusan konsumen dalam pembelian barang elektronik secara kredit pada PT Columbus Megah Sentra Sarana Cabang Berau. Hal ini terbukti dari nilai koefisien regresinya yang paling tinggi dibandingkan dimensi lainnya yaitu 0,552 .

Nilai koefisien determinasi ( $R$ Square) sebesar 0,685 sehingga dapat diindikasikan bahwa keputusan konsumen dalam pembelian barang elektronik secara kredit pada PT Columbus Megah Sentra Sarana Cabang Berau dapat dijelaskan oleh faktor kebudayaan, sosial, pribadi dan psikologis sebesar $68,5 \%$, sedangkan sisanya sebesar $31,5 \%$ dijelaskan oleh variabel lain yang tidak digunakan dalam penelitian ini. Nilai R Square sebesar 0,685 termasuk dalam kategori baik/kuat (nilai R Square >0,5) sebagaimana pendapat Lind (2002) dalam Suharyadi dan Purwanto (2012:217).

Hasil uji t mengenai pengaruh signifikansi masingmasing variabel bebas, menunjukkan bahwa faktorfaktor yang mempunyai pengaruh signifikan yaitu faktor kebudayaan, faktor sosial dan faktor pribadi. Sedangkan faktor psikologis tidak berpengaruh signifikan terhadap keputusan konsumen dalam pembelian barang elektronik secara kredit pada PT Columbus Megah Sentra Sarana Cabang Berau. Sehingga hipotesis yang menyatakan bahwa diduga faktor kebudayaan, faktor sosial, faktor pribadi dan faktor psikologis secara parsial mempunyai pengaruh yang signifikan terhadap keputusan konsumen dalam pembelian barang elektronik secara kredit pada PT Columbus Megah Sentra Sarana Cabang Berau (H1) dapat diterima sebagian dan sebagian lainnya ditolak.

Hasil uji F menunjukkan bahwa F-hitung $(47,30)>$ F-tabel $(2,48)$ dengan tingkat signifikansi 0,000 jauh lebih kecil dari 0,05 (probability), sehingga hipotesis yang menyatakan bahwa diduga faktor kebudayaan, faktor sosial, faktor pribadi dan faktor psikologis secara simultan mempunyai pengaruh yang signifikan terhadap keputusan konsumen dalam pembelian barang elektronik secara kredit pada PT Columbus Megah Sentra Sarana Cabang Berau (H2) dapat diterima.

\section{SIMPULAN DAN SARAN}

\section{SIMPULAN}

1. Hasil uji t menunjukkan bahwa faktor-faktor yang mempunyai pengaruh signifikan yaitu 
faktor kebudayaan, faktor sosial dan faktor pribadi. Sedangkan faktor psikologis tidak berpengaruh signifikan terhadap keputusan konsumen dalam pembelian barang elektronik secara kredit pada PT Columbus Megah Sentra Sarana Cabang Berau. Sehingga hipotesis poin 1 dapat diterima sebagian dan sebagian lainnya ditolak.

2. Hasil uji F menunjukkan bahwa faktor kebudayaan, faktor sosial, faktor pribadi dan faktor psikologis secara simultan mempunyai pengaruh yang signifikan terhadap keputusan konsumen dalam pembelian barang elektronik secara kredit pada PT Columbus Megah Sentra Sarana Cabang Berau, sehingga hipotesis poin 2 dapat diterima.

\section{SARAN}

1. PT Columbus Megah Sentra Sarana Cabang Berau harus mengetahui faktor-faktor apa saja yang berpengaruh dalam keputusan pembelian sehingga dapat menambah konsumen dan meningkatkan penda-patannya.

2. Faktor sosial yang mempunyai pengaruh dominan, terutama adanya referensi yang diterima konsumen dari teman kerja, keluarga maupun teman-teman sepergaulan konsumen, maka strategi yang layak dikembangkan bagi PT Columbus Megah Sentra Sarana Cabang Berau adalah dengan personal selling atau dengan penjualan tatap muka serta promosi dari mulut ke mulut akan lebih efektif dalam meningkatkan penjualannya.

\section{DAFTAR PUSTAKA}

Alma, Buchari. 2016. Manajemen Pemasaran dan Pemasaran Jasa, Edisi Revisi. Alfabeta, Bandung.

Anonim. 2012. Al-Quran dan Terjemah-nya. Departemen Agama RI, Jakarta.

Arikunto, Suharsimi. 2013. Prosedur Penelitian Suatu Pendekatan Praktik. Rineka Cipta, Jakarta.

Assauri, Sofjan. 2015. Manajemen Pemasaran: Dasar, Konsep dan Strategi, RajaGrafindo, Jakarta.

Djarwanto, PS. dan Pangestu Subagyo. 2011. Statistik Induktif, Edisi 4. BPFE, Yogyakarta.

Ghozali, Imam. 2013. Aplikasi Analisis Multivariate dengan Program SPSS, Edisi 7. Badan Penerbit Universitas Diponegoro, Semarang.

Huwaida, Hikmayanti. 2016. Analisis Faktor-faktor yang Mempengaruhi Keputusan Pembelian
Telepon Genggam. Jurnal INTEKNA, Volume 16, No.1, Mei 2016: 1-100, ISSN 1412-5609.

Irawan, Selamet. 2016. Pengaruh Brand Image Terhadap Keputusan Pem-belian Mobil Merek Avanza Pada PT Toyota Sumber Harapan di Tanjung Redeb. Skripsi. Sekolah Tinggi Ilmu Ekonomi Muhammadiyah Tanjung Redeb, Berau.

Kotler, Philip dan Gary Armstrong. 2012. Prinsipprinsip Pemasaran, Edisi. 13, Jilid 1. Erlangga, Jakarta.

Kotler, Philip dan Kevin Lane Keller. 2016. Manajemen Pemasaran, Jilid I, Edisi ke-13. Erlangga, Jakarta.

Lupiyoadi, Rambat. 2016. Manajemen Pemasaran Jasa Berbasis Kom-petensi, Salemba Empat, Jakarta.

Riduwan. 2010. Skala Pengukuran VariabelVariabel Penelitian. Alfa-beta, Bandung.

Sangadji, E.M. dan Sopiah. 2013. Prilaku Konsumen: Pendekatan Praktis. Penerbit Andi, Yogyakarta.

Sekaran, Uma. 2006. Research Methods For Business. Salemba Empat, Jakarta.

Sudomo, ST. 2012. Analisis Faktor-Faktor yang Mempengaruhi Keputusan Pembelian Mobil Toyota Avanza di Propinsi Daerah Istimewa Yogya-karta. Jurnal JBMA, Vol. I, No. 1, Agustus 2012, ISSN: 2252-5483.

Sugiyono. 2016. Metode Penelitian: Kuantitatif, Kualitatif dan $R \& D$. Alfabeta, Bandung.

Suharyadi dan Purwanto. 2012. Statistika: Untuk Ekonomi dan Keuangan Modern, Edisi Kedua, Buku 1. Salemba Empat, Jakarta.

Sunyoto, Danang. 2015. Perilaku Konsumen dan Pemasaran. CAPS, Yogyakarta.

Swastha, Basu. 2015. Manajemen Penjualan, Edisi Ketiga. BPFE, Yogyakarta. 2009. Azas-azas Marketing, Edisi Ketiga, Cetakan Ketujuh. Liberty, Yogyakarta.

Swastha, Basu dan Irawan. 2015. Manajemen Pemasaran Modern. Liberty, Yogyakarta. 